\title{
Mucus plugging on computed tomography and chronic bronchitis in chronic obstructive pulmonary disease
}

\author{
Victor Kim" ${ }^{*}$, Wojciech R. Dolliver ${ }^{2}$, Hrudaya P. Nath ${ }^{3}$, Scott A. Grumley ${ }^{3}$, Nina Terry ${ }^{3}$, Asmaa Ahmed ${ }^{3}$, \\ Andrew Yen ${ }^{4}$, Kathleen Jacobs ${ }^{4}$, Seth Kligerman ${ }^{4}$ and Alejandro A. Diaz ${ }^{2}$ the COPDGene Investigators
}

\section{To the Editor,}

Chronic bronchitis $(\mathrm{CB})$ is associated with more dyspnea, increased respiratory exacerbations, reduced exercise capacity, and mortality [1]. The hallmark of CB is mucus overproduction and goblet cell hyperplasia [2]. Mucus plugging (MP) on CT scan has been associated with decreased lung function, worse health-related quality of life, and amount of emphysema in Chronic Obstructive Pulmonary Disease (COPD) [3]. How it relates to CB in smokers with COPD is unclear. We hypothesized that those with MP are more likely to have $\mathrm{CB}$ compared to those without MP.

We analyzed 2089 randomly chosen subjects from the Genetic Epidemiology Study of COPD (COPDGene) [4]. Briefly, this cohort was comprised of African American and non-Hispanic White current and former smokers ( $\geq 10$ pack year history) $45-80$ years of age with COPD. Measurement of MP has been described previously [3]. A mucus plug was defined as an opacity that completely occludes the lumen, regardless of the airway size, orientation or generation. Major airways such as the trachea, main stem and lobar bronchi were excluded. In a standardized fashion, all airway paths were examined in each out of 18 bronchopulmonary segments of both lungs. An MP score was generated for each CT scan as an aggregation of the number of bronchopulmonary segments with

*Correspondence: victor.kim@tuhs.temple.edu

1 Lewis Katz School of Medicine at Temple University, 3401 North Broad Street, 785 Parkinson Pavilion, Philadelphia, PA 19140, USA

Full list of author information is available at the end of the article
MP (0-18). If a CT scan required more than one reading, the final MP score was an average of the scores from two or three readers.

We divided subjects into those with at least one airway plugged with mucus (MP+) and those without MP (MP-). Additionally, based on prior research in asthma showing that mucus plugging of $\geq 4$ segments was associated with worse lung function [5], we divided subjects into those with an MP score $\geq 4$ and compared them to those with an MP score $<4$. We compared subject characteristics between groups with either an unpaired $t$ test or Chi-square test. Odds ratios for CB were calculated with MP scores using multivariable logistic regression models. Covariates included demographics, lung function, smoking, and radiologic parameters.

Subject characteristics are presented in Table 1. 658 (31.5\%) subjects had mucus plugging on CT scan. 133 (6.4\%) subjects had an MP score of $\geq 4$. Compared to the $\mathrm{MP}-$ group, the $\mathrm{MP}+$ group was more likely to have CB by either the classic definition (cough and phlegm for at least 3 months/year for 2 consecutive years, 29.2 vs. $22.9 \%$ ) or the Saint George's Respiratory Questionnaire (SGRQ) definition (cough and phlegm for the past 4 weeks almost every day or several days a week, 39.1 vs. $25.4 \%$ ). In the $\mathrm{MP} \geq 4$ group, the differences were more significant with $57.7 \%$ and $41.4 \%$ of the subjects having SGRQ CB and classic CB, respectively, compared to $27.6 \%$ and $23.8 \%$ of the $\mathrm{MP}<4$ group. In those with classic CB $(n=519), 36.9 \%$ of them had MP compared to $29.7 \%$ of those without classic CB $(\mathrm{n}=1570, \mathrm{p}=0.002) .10 .6 \%$ of the classic CB group had original author(s) and the source, provide a link to the Creative Commons licence, and indicate if changes were made. The images or other third party material in this article are included in the article's Creative Commons licence, unless indicated otherwise in a credit line to the material. If material is not included in the article's Creative Commons licence and your intended use is not permitted by statutory regulation or exceeds the permitted use, you will need to obtain permission directly from the copyright holder. To view a copy of this licence, visit http://creativecommons.org/licenses/by/4.0/. The Creative Commons Public Domain Dedication waiver (http://creativeco mmons.org/publicdomain/zero/1.0/) applies to the data made available in this article, unless otherwise stated in a credit line to the data. 
Table 1 Subject characteristics

\begin{tabular}{|c|c|c|c|c|c|c|}
\hline & $M P+(n=658)$ & $M P-(n=1431)$ & $p$ & $M P \geq 4(n=133)$ & $M P<4(n=1956)$ & $p$ \\
\hline Age (years) & $64.7 \pm 8.8$ & $62.6 \pm 8.5$ & $<0.0001$ & $64.7 \pm 8.8$ & $63.2 \pm 8.6$ & 0.064 \\
\hline $\mathrm{BMI}\left(\mathrm{kg} / \mathrm{m}^{2}\right)$ & $27.1 \pm 5.8$ & $28.2 \pm 6.0$ & $<0.0001$ & $26.2 \pm 6.3$ & $28.0 \pm 6.0$ & 0.001 \\
\hline Gender ( $\%$ male) & 51.1 & 57.2 & 0.009 & 47.4 & 55.8 & 0.059 \\
\hline Race (\% non-Hispanic White) & 81.6 & 74.3 & $<0.0001$ & 85.7 & 76 & 0.010 \\
\hline Currently smoking (\%) & 36.5 & 42.8 & 0.007 & 45.9 & 40.4 & 0.218 \\
\hline Smoking history (pack-years) & $52.6 \pm 29.2$ & $50.3 \pm 25.7$ & 0.071 & $50.8 \pm 30.6$ & $51.1 \pm 26.6$ & 0.920 \\
\hline Phlegm 3 months or more (\%) & 44.4 & 36.1 & $<0.0001$ & 60.5 & 37.2 & $<0.0001$ \\
\hline Chronic bronchitis classic def (\%) & 29.2 & 22.9 & 0.002 & 41.4 & 23.8 & $<0.0001$ \\
\hline Chronic bronchitis SGRQ def (\%) & 39.1 & 25.4 & $<0.0001$ & 57.7 & 27.6 & $<0.0001$ \\
\hline SGRQ & $42.3 \pm 21.6$ & $33.3 \pm 22.7$ & $<0.0001$ & $45.4 \pm 21.9$ & $35.4 \pm 22.7$ & $<0.0001$ \\
\hline $\mathrm{mMRC}$ & $2.25 \pm 1.41$ & $1.72 \pm 1.46$ & $<0.0001$ & $2.45 \pm 1.33$ & $1.85 \pm 1.47$ & $<0.0001$ \\
\hline FEV1\% predicted & $47.5 \pm 20.8$ & $61.8 \pm 22.9$ & $<0.0001$ & $42.8 \pm 18.7$ & $58.3 \pm 23.2$ & $<0.0001$ \\
\hline FVC\% predicted & $75.9 \pm 20.0$ & $84.8 \pm 19.9$ & $<0.0001$ & $73.2 \pm 17.7$ & $82.6 \pm 20.3$ & $<0.0001$ \\
\hline FEV1/FVC & $0.46 \pm 0.13$ & $0.54 \pm 0.13$ & $<0.0001$ & $0.44 \pm 0.13$ & $0.53 \pm 0.13$ & $<0.0001$ \\
\hline \%emphysema & $16.0 \pm 13.6$ & $11.2 \pm 11.9$ & $<0.0001$ & $14.5 \pm 13.0$ & $12.6 \pm 12.6$ & 0.109 \\
\hline \%gas trapping & $44.6 \pm 19.7$ & $32.3 \pm 19.8$ & $<0.0001$ & $46.4 \pm 18.5$ & $35.6 \pm 20.6$ & $<0.0001$ \\
\hline Pi10 & $3.74 \pm 0.14$ & $3.68 \pm 0.13$ & $<0.0001$ & $3.81 \pm 0.16$ & $3.69 \pm 0.13$ & $<0.0001$ \\
\hline WA\%, segmental & $62.8 \pm 3.0$ & $62.0 \pm 3.0$ & $<0.0001$ & $64.0 \pm 3.0$ & $62.2 \pm 3.0$ & $<0.0001$ \\
\hline Exac freq in year prior (no./pt/year) & $0.79 \pm 1.28$ & $0.54 \pm 1.10$ & $<0.0001$ & $1.11 \pm 1.56$ & $0.59 \pm 1.13$ & $<0.0001$ \\
\hline \% With sev exac in year prior (\%) & 23.1 & 16.8 & 0.001 & 29.3 & 18.0 & 0.001 \\
\hline
\end{tabular}

Data are expressed as mean \pm SD or percent

an $\mathrm{MP}$ score $\geq 4$ compared to $5.0 \%$ of those without classic CB $(\mathrm{p}<0.0001)$. Similar values were found when comparing those with and without SGRQ CB (38.8 vs. $25.1 \%, \mathrm{p}<0.0001$ for $\mathrm{MP}+\mathrm{vs}$. MP- and 11.4 vs. $3.5 \%$, $\mathrm{p}<0.0001$ for $\mathrm{MP} \geq 4$ vs. $\mathrm{MP}<4$ ). Dyspnea, healthrelated quality of life, and lung function were worse in the MP+ group ( $<<0.05$ for all). Percent emphysema, percent gas trapping, airway wall thickness, exacerbation frequency and severe exacerbation frequency were all significantly higher in the MP+ group $(\mathrm{p}<0.05$ for all). Except for \%emphysema, findings were similarly significant in the $\mathrm{MP} \geq 4$ group compared to the $\mathrm{MP}<4$ group.

Odds ratios (OR) for classic CB and SGRQ CB are shown in Table 2. MP+ was associated with an OR of 1.21 and 1.38 for classic CB and SGRQ CB, respectively when adjusting for demographics, lung function, smoking, and CT measures of emphysema and airway wall thickness. Similarly, MP $\geq 4$ was associated with an OR of 1.67 and 2.05 for classic CB and SGRQ CB, respectively.

These data also show that more subjects with MP, looking at two different thresholds (MP+ versus-and $M P \geq 4$ versus $<4$ ) had $C B$ using two different definitions. Additionally, regardless of the presence or absence of $\mathrm{CB}$, those with MP have worse symptoms, health-related quality of life and lung function compared to those without MP, showing that radiographic assessment of MP
Table 2 Odds ratios (OR) for chronic bronchitis

\begin{tabular}{ccccc}
\hline Classic CB & Model 1 & Model 2 & Model 3 & Model 4 \\
\hline MP+ & $1.48(1.20$, & $1.29(1.03$, & $1.20(0.96$, & $1.21(0.95$ \\
& $1.83)$ & $1.61)$ & $1.51)$ & $1.53)$ \\
MP $\geq$ & $2.38(1.65$, & $2.06(1.41$, & $1.79(1.22$, & $1.67(1.12$, \\
& $3.44)$ & $2.99)$ & $2.64)$ & $2.49)$ \\
SGRQ CB & & & & \\
MP+ & $2.07(1.60$, & $1.50(1.14$, & $1.43(1.07$, & $1.38(1.03$, \\
& $2.68)$ & $1.97)$ & $1.90)$ & $1.85)$ \\
$M P \geq 4$ & $3.68(2.29$, & $2.50(1.53$, & $2.28(1.35$, & $2.05(1.20$ \\
& $5.91)$ & $4.10)$ & $3.85)$ & $3.49)$ \\
\hline
\end{tabular}

Data represent $\mathrm{OR}(95 \% \mathrm{Cl})$. Covariates: Model 1: age, gender, race. Model 2: age, gender, race, and FEV1\%predicted. Model 3: age, gender, race, FEV1\% predicted, current smoking and pack year history. Model 4: age, gender, race, FEV1\% predicted, current smoking and pack year history, Pi10 and \%emphysema

provides complementary information to the clinical assessment of $\mathrm{CB}$.

Plugging of the small airways is a central pathologic feature of COPD. In a large study of pathologic specimens, patients with worse lung function were more likely to have small airway mucus luminal occlusion [6]. Radiologically, MP has been linked to severity of airflow obstruction, eosinophilic inflammation, and interleukin-4 blood levels in asthma [5, 7]. In two smaller studies, MP was associated with worse lung function and healthrelated quality of life in smokers with and without COPD, 
but neither $\mathrm{CB}$ nor eosinophilia [3, 8]. To date, this is the first study finding a significant association between mucus plugging and $\mathrm{CB}$ in a large cohort of COPD subjects. While the percent of our MP+ subjects who had $\mathrm{CB}$ was similar compared to prior studies, our findings likely differ because of the size of our cohort and differences in subject characteristics (other studies included never smokers and smokers without airflow obstruction).

The relationship between mucus plugging and emphysema is an interesting one. More mucus plugs have been found in COPD subjects with worse airflow obstruction; additionally, more emphysema is seen in COPD patients with worse airflow obstruction. Previous smaller studies in smokers with and without COPD have found weak but significant correlations between mucus plugging scores and percent emphysema [3, 8]. Our analysis was restricted to those with COPD, and we found statistically different amounts of percent emphysema between those with and without mucus plugs but the difference was not great. This suggests that mucus plugging may play a role in the pathophysiology of airflow obstruction in COPD, independent of emphysema.

We found that using a high threshold for MP scores $(\geq 4)$ was significantly associated with $\mathrm{CB}$, particularly when defined using the SGRQ. This may be related to the SGRQ CB definition identifying "active" symptoms (cough and phlegm in the past 4 weeks), compared to the classic CB definition which is better at identifying chronic symptoms (2 years). However, the higher threshold of MP was only present in 6.4\%, suggesting that using any MP as a threshold may be more practical. Regardless of the definition, in this well-characterized cohort of COPD subjects, MP on CT scan was significantly associated with CB. Compared to those without MP, those with MP had worse symptoms, health-related quality of life, and lung function regardless of the presence or absence of CB. The findings suggest that imaging is a useful tool to objectively measure mucus dysfunction, a central pathophysiologic feature of CB. Further study is necessary to identify the consequences of MP on other patient reported outcomes.

\footnotetext{
Acknowledgements

Grant Support and Disclaimer: The project described was supported by Award Number U01 HL089897 and Award Number U01 HL089856 from the National Heart, Lung, and Blood Institute. The content is solely the responsibility of the authors and does not necessarily represent the official views of the National Heart, Lung, and Blood Institute or the National Institutes of Health. COPD Foundation Funding: COPDGene is also supported by the COPD Foundation through contributions made to an Industry Advisory Board comprised of AstraZeneca, Boehringer-Ingelheim, Genentech, GlaxoSmithKline, Novartis, Pfizer, Siemens, and Sunovion. COPDGene ${ }^{\circledR}$ Investigators - Core Units: Administrative Center: James D. Crapo, MD (PI); Edwin K. Silverman, MD, PhD (PI); Barry J. Make, MD; Elizabeth A. Regan, MD, PhD. Genetic Analysis Center: Terri Beaty, PhD; Ferdouse Begum, PhD; Peter J. Castaldi, MD, MSc; Michael Cho, MD; Dawn L. DeMeo, MD, MPH; Adel R. Boueiz, MD; Marilyn G. Foreman, MD, MS; Eitan Halper-Stromberg; Lystra P. Hayden, MD, MMSc;
}

Craig P. Hersh, MD, MPH; Jacqueline Hetmanski, MS, MPH; Brian D. Hobbs, MD; John E. Hokanson, MPH, PhD; Nan Laird, PhD; Christoph Lange, PhD; Sharon M. Lutz, PhD; Merry-Lynn McDonald, PhD; Margaret M. Parker, PhD; Dmitry Prokopenko, Ph.D; Dandi Qiao, PhD; Elizabeth A. Regan, MD, PhD; Phuwanat Sakornsakolpat, MD; Edwin K. Silverman, MD, PhD; Emily S. Wan, MD; Sungho Won, PhD. Imaging Center: Juan Pablo Centeno; Jean-Paul Charbonnier, PhD; Harvey O. Coxson, PhD; Craig J. Galban, PhD; MeiLan K. Han, MD, MS; Eric A. Hoffman, Stephen Humphries, PhD; Francine L. Jacobson, MD, MPH; Philip F. Judy, PhD; Ella A. Kazerooni, MD; Alex Kluiber; David A. Lynch, MB; Pietro Nardelli, PhD; John D. Newell Jr., MD; Aleena Notary; Andrea Oh, MD; Elizabeth A. Regan, MD, PhD; James C. Ross, PhD; Raul San Jose Estepar, PhD; Joyce Schroeder, MD; Jered Sieren; Berend C. Stoel, PhD; Juerg Tschirren, PhD; Edwin Van Beek, MD, PhD; Bram van Ginneken, PhD; Eva van Rikxoort, PhD; Gonzalo Vegas Sanchez-Ferrero, PhD; Lucas Veitel; George R. Washko, MD; Carla G. Wilson, MS; PFT QA Center, Salt Lake City, UT: Robert Jensen, PhD. Data Coordinating Center and Biostatistics, National Jewish Health, Denver, CO: Douglas Everett, PhD; Jim Crooks, PhD; Katherine Pratte, PhD; Matt Strand, PhD; Carla G. Wilson, MS. Epidemiology Core, University of Colorado Anschutz Medical Campus, Aurora, CO: John E. Hokanson, MPH, PhD; Gregory Kinney, MPH, PhD; Sharon M. Lutz, PhD; Kendra A. Young, PhD. Mortality Adjudication Core: Surya P. Bhatt, MD; Jessica Bon, MD; Alejandro A. Diaz, MD, MPH; MeiLan K. Han, MD, MS; Barry Make, MD; Susan Murray, ScD; Elizabeth Regan, MD; Xavier Soler, MD; Carla G. Wilson, MS. Biomarker Core: Russell P. Bowler, MD, PhD; Katerina Kechris, PhD; Farnoush Banaei-Kashani, Ph.D. COPDGene ${ }^{\circledR}$ Investigators Clinical Centers: Ann Arbor VA: Jeffrey L. Curtis, MD; Perry G. Pernicano, MD. Baylor College of Medicine, Houston, TX: Nicola Hanania, MD, MS; Mustafa Atik, MD; Aladin Boriek, PhD; Kalpatha Guntupalli, MD; Elizabeth Guy, MD; Amit Parulekar, MD; Brigham and Women's Hospital, Boston, MA: Dawn L. DeMeo, MD, MPH; Alejandro A. Diaz, MD, MPH; Lystra P. Hayden, MD; Brian D. Hobbs, MD; Craig Hersh, MD, MPH; Francine L. Jacobson, MD, MPH; George Washko, MD. Columbia University, New York, NY: R. Graham Barr, MD, DrPH; John Austin, MD; Belinda D'Souza, MD; Byron Thomashow, MD. Duke University Medical Center, Durham, NC: Neil MacIntyre Jr., MD; H. Page McAdams, MD; Lacey Washington, MD. Grady Memorial Hospital, Atlanta, GA: Eric Flenaugh, MD; Silanth Terpenning, MD. HealthPartners Research Institute, Minneapolis, MN: Charlene McEvoy, MD, MPH; Joseph Tashjian, MD. Johns Hopkins University, Baltimore, MD: Robert Wise, MD; Robert Brown, MD; Nadia N. Hansel, MD, MPH; Karen Horton, MD; Allison Lambert, MD, MHS; Nirupama Putcha, MD, MHS. Lundquist Institute for Biomedical Innovationat Harbor UCLA Medical Center, Torrance, CA: Richard Casaburi, PhD, MD; Alessandra Adami, PhD; Matthew Budoff, MD; Hans Fischer, MD; Janos Porszasz, MD, PhD; Harry Rossiter, PhD; William Stringer, MD. Michael E. DeBakey VAMC, Houston, TX: Amir Sharafkhaneh, MD, PhD; Charlie Lan, DO. Minneapolis VA: Christine Wendt, MD; Brian Bell, MD; Ken M. Kunisaki, MD, MS. National Jewish Health, Denver, CO: Russell Bowler, MD, PhD; David A. Lynch, MB. Reliant Medical Group, Worcester, MA: Richard Rosiello, MD; David Pace, MD. Temple University, Philadelphia, PA: Gerard Criner, MD; David Ciccolella, MD; Francis Cordova, MD; Chandra Dass, MD; Gilbert D'Alonzo, DO; Parag Desai, MD; Michael Jacobs, PharmD; Steven Kelsen, MD, PhD; Victor Kim, MD; A. James Mamary, MD; Nathaniel Marchetti, DO; Aditi Satti, MD; Kartik Shenoy, MD; Robert M. Steiner, MD; Alex Swift, MD; Irene Swift, MD; Maria Elena VegaSanchez, MD. University of Alabama, Birmingham, AL: Mark Dransfield, MD; William Bailey, MD; Surya P. Bhatt, MD; Anand Iyer, MD; Hrudaya Nath, MD; J. Michael Wells, MD. University of California, San Diego, CA: Douglas Conrad, MD; Xavier Soler, MD, PhD; Andrew Yen, MD. University of lowa, lowa City, IA: Alejandro P. Comellas, MD; Karin F. Hoth, PhD; John Newell Jr., MD; Brad Thompson, MD. University of Michigan, Ann Arbor, Ml: MeiLan K. Han, MD MS; Ella Kazerooni, MD MS; Wassim Labaki, MD MS; Craig Galban, PhD; Dharshan Vummidi, MD. University of Minnesota, Minneapolis, MN: Joanne Billings, MD; Abbie Begnaud, MD; Tadashi Allen, MD. University of Pittsburgh, Pittsburgh, PA: Frank Sciurba, MD; Jessica Bon, MD; Divay Chandra, MD, MSc; Carl Fuhrman, MD; Joel Weissfeld, MD, MPH. University of Texas Health, San Antonio, San Antonio, TX: Antonio Anzueto, MD; Sandra Adams, MD; Diego Maselli-Caceres, MD; Mario E. Ruiz, $M D ;$ Harjinder Singh.

\section{Authors' contributions}

VK conceived and designed the analysis plan, performed data analysis and contributed significantly to the writing of the manuscript; WRD, HPN, SAG, NT, $A A, A Y, K J$, and SK generated much of the data and contributed significantly to the writing of the manuscript; $A D$ contributed significantly to the data analysis and the writing of the manuscript. All authors read and approved the final manuscript. 


\section{Funding}

The National Heart, Lung, and Blood Institute (NHLBI) supports the COPDGene Study [Grants U01 HL089897, U01 HL089856]. The COPD Foundation also supports the COPDGene Study [Grant NCT00608764] through contributions made to an Industry Advisory Committee composed of AstraZeneca, Boehringer-Ingelheim, GlaxoSmithKline, Novartis, and Sunovion. Dr. Diaz is supported by the NHLBI [Grants R01HL149861 and R01-HL133137] and the Brigham and Women's Hospital Minority Faculty Career Development Award.

\section{Availability of data and materials}

The datasets used and/or analysed during the current study are available from the corresponding author on reasonable request.

\section{Declarations}

\section{Ethics approval and consent to participate}

Written informed consent was obtained from all participants prior to enrollment and the study protocol was approved by the institutional review boards of all participating centers. Consent to participate is not applicable.

\section{Consent for publication}

Not applicable.

\section{Competing interests}

VK reports personal fees from Gala Therapeuatics, personal fees from ABIM Critical Care Testwriting Committee, personal fees from AstraZeneca, personal fees from Boehringer Ingelheim, outside the submitted work; WRD, HPN, SAG, $N T, A A, A Y, K J, S K$, and $A D$ have no competing interests to declare.

\section{Author details}

1 Lewis Katz School of Medicine at Temple University, 3401 North Broad Street, 785 Parkinson Pavilion, Philadelphia, PA 19140, USA. ${ }^{2}$ Division of Pulmonary and Critical Care Medicine, Brigham and Women's Hospital, Boston, MA, USA. ${ }^{3}$ Department of Radiology, University of Alabama at Birmingham, Birmingham, AL, USA. ${ }^{4}$ Department of Radiology, University of California San Diego, San Diego, CA, USA.

Received: 18 February 2021 Accepted: 11 April 2021

Published online: 17 April 2021

\section{References}

1. Kim V, Criner GJ. The chronic bronchitis phenotype in chronic obstructive pulmonary disease: features and implications. Curr Opin Pulm Med. 2015;21:133.

2. Kim V, Oros M, Durra H, Kelsen S, Aksoy M, Cornwell WD, Rogers TJ, Criner GJ. Chronic bronchitis and current smoking are associated with more goblet cells in moderate to severe COPD and smokers without airflow obstruction. PLOS ONE. 2015;10:e0116108.

3. Okajima Y, Come CE, Nardelli P, Sonavane SK, Yen A, Nath HP, Terry N, Grumley SA, Ahmed A, Kligerman S, et al. Luminal plugging on chest CT scan: association with lung function, quality of life, and COPD clinical phenotypes. Chest. 2020;158:121-30.

4. Regan EA, Hokanson JE, Murphy JR, Make B, Lynch DA, Beaty TH, CurranEverett D, Silverman EK, Crapo JD. Genetic epidemiology of COPD (COPDGene) study design. COPD. 2010;7:32.

5. Dunican EM, Elicker BM, Gierada DS, Nagle SK, Schiebler ML, Newell JD, Raymond WW, Lachowicz-Scroggins ME, Di Maio S, Hoffman EA, et al. Mucus plugs in patients with asthma linked to eosinophilia and airflow obstruction. J Clin Invest. 2018;128:997-1009.

6. Hogg JC, Chu F, Utokaparch S, Woods R, Elliott WM, Buzatu L, Cherniack RM, Rogers RM, Sciurba FC, Coxson HO, Pare PD. The nature of smallairway obstruction in chronic obstructive pulmonary disease. N Engl J Med. 2004;350:2645.

7. Svenningsen S, Haider E, Boylan C, Mukherjee M, Eddy RL, Capaldi DPI, Parraga G, Nair P. CT and functional MRI to evaluate airway mucus in severe asthma. Chest. 2019;155:1178-89.

8. Dunican EM, Elicker BM, Henry T, Gierada DS, Schiebler ML, Anderson W, Barjaktarevic I, Barr RG, Bleecker ER, Boucher RC, et al. Mucus plugs and emphysema in the pathophysiology of airflow obstruction and hypoxemia in smokers. Am J Respir Crit Care Med. 2020. https://doi.org/ 10.1164/rccm.202006-22480C.

\section{Publisher's Note}

Springer Nature remains neutral with regard to jurisdictional claims in published maps and institutional affiliations.
Ready to submit your research? Choose BMC and benefit from:

- fast, convenient online submission

- thorough peer review by experienced researchers in your field

- rapid publication on acceptance

- support for research data, including large and complex data types

- gold Open Access which fosters wider collaboration and increased citations

- maximum visibility for your research: over $100 \mathrm{M}$ website views per year

At BMC, research is always in progress.

Learn more biomedcentral.com/submissions 